Article

\title{
Ambivalence of Professional Socialization in Social and Educational Professions
}

\author{
Gabriella Pusztai (iD) and Cintia Csók* (iD \\ Institute of Educational Studies and Cultural Management, University of Debrecen, 4032 Debrecen, Hungary; \\ pusztai.gabriella@arts.unideb.hu \\ * Correspondence: csokcintia@gmail.com
}

Received: 14 June 2020; Accepted: 14 August 2020; Published: 17 August 2020

\begin{abstract}
The factors that promote successful professional socialization have become a primary focus of study through the expansion of higher education. The structural changes in the labor market of post-socialist countries such as Hungary over the last three decades have presented a challenge to the training areas of social and educational professions. In Hungary, these professions are not very attractive, the degrees have a low profitability, and the working people already face great challenges when looking for a job. Our research question is whether the traditionally theoretical character of higher education is able to keep up with the dynamic changes in the reality of the labor market. By interviewing 20 professionals about their professional experience and career plans, we tried to answer the questions about the low attractiveness and low retention rate of these professions. We compared the careers of bachelor's graduates with degrees in social work, youth work, and education. The qualitative analysis showed that professionals whose training included more field exercises and supervision were more successful. They had increased their professional and social capital, and these helped them to integrate into the labor market.
\end{abstract}

Keywords: higher education; helping professions; professional socialization

\section{Introduction}

As a result of the expansion of higher education, the operation of institutions has undergone a profound transformation: The structures of institutions have changed, the range of courses has widened, and the cultural and social composition of students has diversified (Archer 1982; Castro and Levy 2001). In Hungary, the process started in the wake of the political transformation of 1989-1990 (Pusztai and Szabó 2008; Pusztai et al. 2016). The political changes had a massive impact on the helping professions, as their work had previously been restricted by state socialism for reasons of prestige and ideology. State propaganda in Eastern and Central Europe denied the existence of poverty, deviance, and domestic or school problems in their countries (Ferge 1997; Csoba et al. 2014). After the transformation, however, social problems were given publicity, and higher education launched targeted degree programs that prepared students for helping disadvantaged social groups with their advancement. Other majors were aimed at training professionals who were to promote disadvantaged students' academic performance and social integration in particular.

Our present study focuses on social professions and examines the professional socialization of the first large-scale cohort of social worker and school youth worker graduates after the launch of the new programs. The relevance of this research is that the degree program was unknown and then gained a lot of popular enrollment, followed very shortly by a drastic decline. The structural change of higher education within the Bologna process, which introduced two-cycle degree programs, led to a fall in the number of students after 2005. Whereas in 2009 a total of 2318 students received degrees in social professions, this number dropped to 1483 in 2010 . Those who had originally 
been working in this field did not have proper qualifications, so the first task was to retrain the existing workforce. Therefore, owing to the full-time employment of most students, a lot of emphasis was put on flexible student timetables and part-time education. The reason for the subsequent fall in student numbers was that, with time, the number of people enrolling for in-service training declined, and high-school graduates showed little interest in this field (Balogh et al. 2015). Even in the second quarter of 2019, vacancies in social work represented $4.1 \%$ of all vacancies in the country (Hungarian Central Statistical Office (KSH) (2019)). The social problems that these professions address have not ceased to exist. The question is whether this trend has anything to do with the international tendency that welfare systems are losing ground and, at the same time, natural support systems such as families, communities, and the private sector are gaining importance (Lodigiani and Pesenti 2014; Csoba et al. 2014).

The novelty of our approach is that our study compares the situation of social professionals ${ }^{1}$ with that of Education BA graduates (adult educators and teaching assistants). What all these professions have in common is that they have emerged from philanthropic volunteerism and are related to the ideas of the caring state: Providing equal treatment, enhancing self-development, and improving social cohesion. Albeit in different areas and different stages of life, all of the above professions aim at giving social help. In addition, they all seek to address problems through individual and collective renewal and change (Kleisz 2005).

We focus on professions that deal with social and educational problems on a non-profit basis. According to statistics, the majority of professionals work in the public sector (e.g., schools, child protection, and social welfare). According to official data on the professional careers of university graduates, statistics do not count social and educational professionals as working in their own profession when they start working as self-employed individuals (Csók 2020). Between 2000 and 2015 , the number of people employed in health and social care increased by $42 \%$ in Organisation for Economic Co-operation and Development (OECD) countries. Since the proportion of them was $6.8 \%$ in Hungary, school social work services were strengthened, and 1500 new jobs were created in 2018 (Hungarian Central Statistical Office (KSH) (2018); Máté 2018). By comparing social majors (school youth work, social work) with education majors (adult education, teaching assistants), we pose the following questions: What do graduates regard as the greatest strength and weakness of their training? What kinds of career paths are there for helping professionals?

\section{The Interpretation of Professional Socialization}

In social or, broadly speaking, helping professions, professional socialization plays an even more important role than in other fields. It is generally expected that it should be part of the training (Barretti 2004a; Weiss et al. 2004; Miller 2013) even though there is no international consensus on the content of the curriculum (Weiss et al. 2004). A common main goal, however, is to create strong commitment in future professionals by strengthening the essential values needed for the profession (Abbott 1988; Weiss et al. 2004). In general, training programs with strong framing (Bernstein 1971) have higher prestige; however, in the case of the careers we studied, even the institutional backgrounds were diverse. Hungarian society shows great spatial diversity with specific local or regional problems; that is why the identification of problems and the solutions to them are different.

Part of international research identifies three related stages of professional socialization: Early, pre-professional socialization before training begins; socialization during formal training; and post-training work experience and career span (Shuval 1980; Barretti 2004b; Miller 2010, 2013). This three-stage model is typically applied to social professionals as well (Miller 2010, 2013). Other

1 Social professionals (social workers, school youth workers) mainly contribute to the complex management of problems, increase individual and social well-being, and promote social integration in the fields of public education, child welfare, child protection, and the social care system. 
research that does not divide socialization into such distinct phases owing to its ever-altering character indicates a paradigm shift. Circular theories include the element that participants reflect on events and, consequently, their behavior changes constantly. Thus, professional socialization is interpreted as a constructivist process spanning crises and obstacles (Stark et al. 1986; Weidman et al. 2001; Pusztai 2011). For the conceptual framework of our research, we combined Miller's (2010) concept of professional socialization with Weidman's model (Weidman 1989; Weidman et al. 2001).

The first stage, pre-socialization, incorporates prior and anticipatory socialization, and the two intersect (Shuval 1980; Miller 2010). Prior socialization refers to childhood or primary socialization and the bearing that early formative experiences have on an individual (Miller 2010). Anticipatory socialization, on the other hand, can be looked upon as a process leading through crises, building up the individual's career interpretation (Weidman et al. 2001; Miller 2010).

The second stage, formal education, appears to be a purposeful and well-designed construction including content and structural components. The content component is made up of the knowledge base of the profession, i.e., the norms, attitudes, and values as well as the necessary work skills and knowledge conveyed during the educational process. The structure component includes people who fill key roles in the formal training system (faculty, field instructors, fellow students), the hierarchy, other influencing mechanisms (e.g., class composition), and the nature of the sequential process of formal education and training (Miller 2010). As opposed to Miller's categorization, Weidman differentiates between interpersonal, intrapersonal, and integrational dimensions. Whereas the interpersonal dimension contains the frequency, intensity, and nature of student interactions, the intrapersonal one contains the impact of the higher education experience on motivation and attitudes. Lastly, the integrational dimension reveals how students perceive their own integration (Weidman 1989; Pusztai 2011).

The third stage is composed of employment and volunteer practice settings as well as situational adaptation. The latter refers to the theory that individuals' professional socialization can vary depending upon the situations within which they are utilizing their professional selves (Shuval 1980; Miller 2010). On the whole, professional socialization is a sequence of changes, the outcome of which, ideally, is the internalization of professional values, attitudes, and identity (Becker et al. 1961; Miller 2010). Still, owing to individual constructions, it is not a standard process.

\section{Professional Socialization of Trainees in Helping Professions}

In addition to conceptual clarification, empirical research has also commenced. A meta-analysis classified research on professional socialization into three categories and also pointed out its deficiencies (Barretti 2004a). Studies in the first category (the Effect of Professional Education on Attitudes over Time) focused on whether the time or intensity of the training had any impact on the students (Moran 1989; Pardeck and McCallister 1991; Van Soest 1996; Barretti 2004a). In several cases, comparisons were drawn between first-year and graduating students. However, as there had been no consensus on which dimensions led to successful socialization, the conclusions were contradictory (Barretti 2004a). Focusing on social and educational professions, no research has been conducted in this category in Hungary.

The theme of the second category, the most numerous one, was the Effect of Professional Education on Values and Ethics. There are, however, the following limits to the extent to which the results of these studies can be generalized: None of the surveys were repeated, there was diversity in research design, and the surveys usually focused on a single training institution. Furthermore, there was also diversity in the number and type of the variables examined, and in certain cases, the method applied was correlational calculation instead of repeated measure design (Barretti 2004a). In Hungary, the research of Nagy (2008) can be classified into this category; they conducted a cross-sectional study among students, comprising specializations as school youth workers, social workers, teachers, and nursery teachers.

There are very few examples of the third category, Qualitative Professional Socialization Studies in Social Work. Small-sample qualitative research was carried out by interviewing or observation. 
The theoretical framework for the interpretation of students' adaptation to professional learning and their acquisition of new roles was phenomenological or symbolic interactionist. These studies drew attention to the broader cultural aspects of the training programs rather than the change in attitudes and the acquisition of values (Barretti 2004a). Interview research on the professional socialization of social and educational professionals has not been conducted in Hungary.

As in the meta-analysis of the literature by Barretti (2004a), Salisu et al. (2019) conducted a systematic review of facilitators and challenges of professional socialization, and a narrative synthesis was used to analyze the available data. They found that eight studies pointed to such challenges of professional socialization, such as incongruence of theory and practice (Zarshenas et al. 2014), disintegration (Dinmohammadi et al. 2017), and focused education (Condon and Sharts-Hopko 2010). However, the researchers pointed to the facilitators of professional socialization, such as professional context (Dinmohammadi et al. 2017), supportive teachers (Curtis et al. 2012), and interactive learning (Holley and Taylor 2009). Research has also confirmed that studies with small samples of interviews are suitable for exploring deep structures and interpersonal problems (Salisu et al. 2019).

Having reviewed wider literature, we also used Barretti (2004a) classification. From among the studies of the first category, which focus on changes during training, it is worth highlighting that of Weiss et al. (2004), who conducted a panel study among students of social work in Israel and the United States, revealing the impact of training programs on professional preferences. It involved 223 students who completed a questionnaire both during their first weeks of study and again after a period of two (in the US) or three years (in Israel), just prior to graduation. Four dependent variables were measured: Preferences for client groups; preferences for social service organizations; preferences for welfare economy sectors; and preferences regarding types of social work practice. They found that the education process did not essentially alter students' professional preferences, although significant decline was observed in certain cases. At the same time, these preferences did not appear to be in line with the changing demands of society. Students were less willing to work with the chronically ill, people with disabilities, the elderly, or the unemployed. Typically, respondents' preferences included working with children and teenagers, though their training hardly inspired them to deal with very disadvantaged social groups.

The second category includes a large-scale Brazilian study focusing on the training of nurses, one of the most researched helping professions. Shinyashiki et al. (2006) examined nursing students in the southeast of Brazil and analyzed the changes in professional values as a function of professional socialization. They conducted a cross-sectional study among 278 students from the four years of the course. Although longitudinal studies are more precise in tracking changes, they opted for a cross-sectional one because of its cost and time efficiency. In order to allow international comparison and to reduce the error margin, they used a questionnaire validated by other researchers. Their data showed that the most significant changes mainly took place between the second and third years. They concluded that the socialization of professional values was strongly influenced by the institution itself and the curriculum, but demographic variables and early (pre-professional) socialization were not to be neglected, either.

Studies that look at the question of professional socialization from the perspective of minority students illustrate the possibility of multiple approaches. An example of the third category is Daniel (2007) research, in which he made semi-structured in-depth interviews with 15 African American and Latino students of social work. His study drew attention to curriculum issues. Respondents pointed out that besides difficulties arising from their cultural and racial isolation, they were faced with a curriculum and compulsory literature that lacked any multicultural approach. Respondents also reported having a feeling of "invisibility", interpersonal conflicts, experiences of marginalization, and difficulties establishing relationships because of stereotypes. Several studies mentioned the lack of pluralism in the institutional environment and pointed out the problem of so-called symbolic racism in social worker training (Basham et al. 1997; Longres and Seltzer 1994; Bowie and Hancock 2000; Weaver 2000; Swank et al. 2001). One of Daniel's (2007) respondents said they were confronted 
with all those negative messages from their peers or office staff right in their first year, which made them "burn out" by their second year. Therefore, it is important to give due consideration to any feedback from minority students, as similar experiences might undermine their motivation necessary for completing their training and might have a negative impact on their career visions and commitment to the profession.

Longitudinal career studies are also suitable for the evaluation of professional socialization, as it is only in retrospect that judgements can be made about how efficient it has been. "In Hungary, a regular higher education career-tracking system has been carried out within the framework of the Graduate Career Tracking System (GCT) since 2007, although there have been large numbers of career-tracking studies preceding it" (Széll et al. 2016, p. 16). A study of the career paths of young helping professionals in the fields of social work and education concluded that, whereas education graduates took a longer time to find a job and not all of them were able to find one matching their qualifications, social workers were less likely to leave their professions. Although education graduates had less favorable results regarding horizontal and vertical congruence (Csók 2020), social workers were also affected by income disadvantages (Benkő 2009; Csók 2020).

\section{Methods}

Our present study focuses on the last stage of the three-phase model of socialization, on the practical experience gained after formal education, and on the career span. However, during the survey of their academic history, former students also reflected upon their professional training, so experiences during formal education were not left out either. When analyzing the quantitative official longitudinal career data, it became clear to us that several elements of the professional socialization process were not examined in this type of research (Csók 2020). That is why we conducted the research based on a qualitative paradigm. Our research question is about how graduates perceive their professional preparation for helping professions.

Our research plan was based on the fact that the above-mentioned helping professions are most relevant in disadvantaged regions; therefore, we decided to interview graduates of two higher education institutions - the University of Debrecen and the University of Nyíregyháza-from the most disadvantaged region of Hungary (Pusztai and Ceglédi 2015). We carried out random sampling and contacted our respondents at random using the databases of the educational institutions. We increased the number of our sample by making official inquiries among the target groups of students. In order to investigate the low attractiveness and low retention in working life, we conducted semi-structured interviews with graduates (May-August 2018) who graduated in 2007, 2009, or 2011. We selected them because there was a suspicion that their transition phase from training to the world of work would be completed. We surveyed 20 people altogether-five from each degree program. As with qualitative surveys in general, the number of samples was small, which does not allow generalizations to be made about the value of training in the labor market. However, we were given insight into young professionals' interpretations of their professional identities shaped by the content, methods, strengths, and weaknesses of the training. A detailed investigation into the career paths revealed the deep structure of the problem. Our study belongs to Barretti's (2004a) third category, small-sample qualitative research.

We then developed an interview plan based on observation of the participants and fieldwork. The framework of the interview was grounded in the results of an earlier quantitative study (Benkő 2009). Our plan focused on four dimensions: Introductory questions, training, labor market experiences, and future plans (Table 1). During the interviews, all four main areas were covered, but we did not interrupt the respondents' thought processes, meaning that the order of the questions was flexible. 
Table 1. Structure of the interview plan.

\begin{tabular}{|c|c|}
\hline Question Blocks & Sub-Questions \\
\hline Introductory questions & age, marital status, number of children, qualifications \\
\hline Training & $\begin{array}{l}\text { longest-lasting memories, actual practical outcomes, strengths of the training, } \\
\text { weaknesses of the training, the social function of the knowledge they acquired } \\
\text { during their studies, career choice (good decision, wrong decision) }\end{array}$ \\
\hline Labor market experiences & $\begin{array}{c}\text { main job tasks and responsibilities, previous work experience, training and } \\
\text { labor market congruence }\end{array}$ \\
\hline Plans for the future & further learning plans, job change or career change, career plans \\
\hline
\end{tabular}

In order to investigate the perception of the preparedness of the graduates, we asked them for a retrospective review. This may, of course, raise questions of validity regarding minor details of the curriculum and the content of their education, but it is likely that former students see their preparedness to use the skills they once acquired quite objectively in the light of the success of their work. We conducted the interviews in person, and each one took about one and a half hours. Data on the demographic characteristics of respondents are given in Table 2.

Table 2. Details about the respondents.

\begin{tabular}{cccccc}
\hline Sex & Age & $\begin{array}{c}\text { Year of } \\
\text { Graduation }\end{array}$ & $\begin{array}{c}\text { Number of } \\
\text { Previous Jobs }\end{array}$ & Current Job \\
\hline $\begin{array}{c}\text { youth } \\
\text { worker }\end{array}$ & $\begin{array}{c}4 \text { women, } \\
1 \text { man }\end{array}$ & $29-39$ & $2007-2011$ & $1-6$ & $\begin{array}{c}\text { child welfare service, social service, youth } \\
\text { area, elderly care, secondary school }\end{array}$ \\
\hline $\begin{array}{c}\text { social } \\
\text { worker }\end{array}$ & 5 women & $29-40$ & $2007-2011$ & $2-5$ & $\begin{array}{c}\text { drug ambulance, addictions department, } \\
\text { basic social service, government office }\end{array}$ \\
\hline $\begin{array}{c}\text { teaching } \\
\text { assistant }\end{array}$ & $\begin{array}{c}3 \text { women, } \\
2 \text { men }\end{array}$ & $30-31$ & $2009-2011$ & $1-6$ & $\begin{array}{c}\text { sales, energy industry, educational } \\
\text { institution, call centers, } \\
\text { catering/hospitality, kindergarten } \\
\text { (English lessons) }\end{array}$ \\
\hline $\begin{array}{c}\text { adult } \\
\text { educator }\end{array}$ & $\begin{array}{c}1 \text { man } \\
\text { 1 momen, }\end{array}$ & $29-32$ & $2009-2011$ & $1-9$ & $\begin{array}{c}\text { storekeeper, unemployed, facility } \\
\text { management company (human } \\
\text { resources), conservation, archery } \\
\text { instructor, catering/hospitality, maternity } \\
\text { leave/child care allowance }\end{array}$ \\
\hline
\end{tabular}

The subsequent analysis and establishment of the categories was the result of a multi-level hierarchical coding process with open, axial, and selective coding (Strauss and Corbin 1990; Strauss and Corbin 1998). During open coding, we decomposed the data (we searched for keywords, key phrases). We organized similar concepts into groups and created categories. Finally, for selective coding, we developed core categories and interpreted the data (Strauss and Corbin 1990; Strauss and Corbin 1998; Goulding and Saren 2010). During the analysis, we followed the methodological principle of personal triangulation in order to minimize the bias associated with subjectivity by involving several researchers (Sántha 2010).

\section{Preparation for Helping Professions in Retrospect}

Below, we present our research findings under the following headings: Graduates' views on their training, their experiences on the labor market, and their plans for the future. According to the answers of the respondents, the characteristics of youth work and social work training showed an equivalent image. Social experts highlighted practice orientation as the main strength of their training, especially in field exercises, where they had the opportunity to recognize different fields of expertise. However, they mentioned the lack of promotion of the use of learned models, methods, and techniques 
in practice as well as more in-depth, specialized knowledge transfer as weaknesses. In contrast to the former, the educational professionals pointed out the strength of theoretical education and called attention to the problem of low working hours and low-intensity practical opportunities.

According to the responses of school youth worker and social worker experts, the practical orientation of the training contributed to the development of knowledge embedded in the profession, thus helping the integration into the labor market. On the basis of the answers, a picture of a path-stable graduate has been drawn, since the respondents were able to find a job within the profession, and, on the other hand, the idea of leaving the career (just the mobility between the different care systems) did not appear in future plans. Controversially, for the adult educators and teaching assistants, the theory orientation of their training provided a convertible knowledge that the interviewees complemented with different qualifications in order to achieve successful employment. This group was identified as path-seeking graduates, as professional insecurity was characteristic regarding their labor market paths and future plans.

\subsection{The Training}

School youth workers, social workers, adult educators, and teaching assistants all highlighted strong group cohesion, forming life-long friendships, the vast knowledge and student-friendly attitude of certain lecturers, and the sense of achievement felt upon a successful exam or the defense of one's thesis as their longest-lasting memories from their years in higher education. Among the actual practical outcomes, respondents mentioned obtaining a degree, personal and professional networking, increasing their knowledge, shaping their outlook on the world, and becoming independent. Graduates in social professions tended to take part in further training in their field (in-service courses, qualifying exams), whereas degrees in education often served as springboards for other degree programs (special teacher, teacher of pedagogy, and Hungarian language and literature, English Studies BA degrees) as well as other tertiary courses for jobs like spokesperson, health insurance and remuneration specialist, telemarketing assistant, special teaching assistant, or sign language interpreter.

The interviewees can be divided into two groups according to whether it was the practical focus or the strong theoretical input that they considered the greatest strength of their training. School youth workers and social workers unanimously opted for the former, highlighting the implementation of theories, accumulation of relationship capital, and a better knowledge of certain professional areas, welfare systems, and client groups. Graduates found that the practical experience they had gained helped them find employment in their profession and guided them in their work. Additionally, the adult educators and teaching assistants mentioned the diversity of theoretical knowledge, the transmission of generic and technical knowledge, and the outcome of engagement in assignments set forth by certain lecturers.

"I was able to put my theoretical knowledge into practice every term. The most exciting was the six-month major practice, which enabled me to try myself as a junior social worker and colleague". (social worker no. 1)

"Well-prepared faculty conveyed knowledge in an appropriate way". (teaching assistant no. 4)

School youth workers' and social workers' answers also overlapped regarding what acquired knowledge and competences they had made the most use of. Both groups emphasized skills needed for everyday life, such as treating people, reacting to certain situations, showing empathy, tolerance, honing communication skills, conducting problem solving, displaying assertiveness, doing analytical thinking, having self-knowledge, and conducting self-reflection. They also mentioned the importance of psychological knowledge and the usefulness of being familiar with the code of ethics. The above list implies that the two degree programs had similar curricula. However, school youth workers pointed out the dominant role of education subjects, which gave the course its unique character. As for the other two majors, adult educators pointed out the utility of having organizing and planning 
skills, while teaching assistants highlighted the importance of psychological knowledge. In addition, although the majority complained about the scarcity of opportunities for practice, they also mentioned the opportunity to get insight into the innerworkings of organizations during visits.

In addition to the strengths, we wanted to know what aspects of their training graduates were the most critical of and what kind of knowledge and competence had proved to be the least useful to their work. We have already mentioned that some social and school youth workers found that it was student-friendly lecturers who made the longest-lasting positive impressions on them. In contrast, other interviewees mentioned some faculty members in a negative context:

"Some lecturers were below standard, and some subjects, which were of great practical value, were underestimated, so I had to seek the knowledge on my own". (youth worker no. 2)

"What I most disliked was that some lecturers kept talking about everything but the course material or did not even turn up in class. They gave us no knowledge but were very demanding at exams". (social worker no. 4)

The role of lecturers as socialization agents is no surprise-whether we speak of strengths or weaknesses-given that they are formative figures in higher education that have an influence on the society of the future and the knowledge and skills of the young generations (Coombs 1968). Interviewees altogether claimed that they were able to utilize all the knowledge acquired during their training. Adult educators and teaching assistants pointed out the issue of subjects they considered useless. Considering that these subjects do contribute to one's erudition and are essential parts of an intellectual's knowledge, such judgements may sound paradoxical. However, students criticized them for taking away time and credits from more pragmatic technical subjects (Vincze 2010; Szabó 2015).

"I think all the knowledge and skills I acquired during my training have contributed to the development of my professional identity and personality". (social worker no. 1)

"To be more specific, I would list all my art history subjects, but I don't even remember their names". (adult educator no. 2)

Finally, our investigation into the features of the degree programs also involved what students missed from their training. Social and school youth workers would welcome more help with implementing the models, methods, and techniques they learned, more thorough teaching of a wider range of specialized knowledge, and the clarification of competence limits. In addition, social workers missed opportunities to practice writing applications and business plans, training in finance and management, and situational practice for job hunting. As the dark side of the strengths listed earlier, adult educators and teaching assistants expressed similar criticism. They found that the strong theoretical input was not counterbalanced by opportunities to put that knowledge into practice. Graduates wished they had received a higher amount of and more intensive practical training.

"I missed specified and applied knowledge, by which I mean implementation, turning acquired information into skills. Also, the recognition of, and compliance with, clear-cut competence boundaries. They are not to train saviors but professionals". (youth worker no. 4)

"I couldn't utilize the theoretical knowledge, no matter how well it was taught, because practical training was deficient". (adult educator no. 1)

School youth workers unanimously claimed not to have regretted their choice of career and would repeatedly decide on the same major, as they thought their profession was in great demand on the job market. Some respondents, however, wished they had taken yet another degree, for example, in physiotherapy or healthcare. Social workers showed a similar tendency to emphasize their commitment to their work in every interview. However, some of them said they might not choose 
the same major if they could start anew, the reasons being the low salary and low prestige of social work. The majority of adult educators did not regret their career choices either, but most of them would enroll in another degree program. Curiously, unlike graduates in the social field, they would not choose a major in the humanities, but in completely different fields. Similarly, teaching assistants would definitely choose another more marketable profession.

"I would make the same choice any time without giving it a second thought. My major, and hence my job, have given me a lot of knowledge, friends, and experiences. But for them, I definitely wouldn't be the same person". (youth worker no. 4)

"Although I love my work, I may not choose this profession again, as we are held in low esteem both financially and socially.". (social worker no. 3)

"It wasn't a bad decision, I made the most of it, but if I could start all over again, I would rather study something related to science or economics". (adult educator no. 3)

"You can't turn back time, but if you could, I would choose another major, sociology or law. Education was not a bad decision, though". (teaching assistant no. 3)

\subsection{Experiences on the Labor Market}

The school youth workers and social workers we interviewed were working in their own profession in secondary schools, child welfare services, government offices, and basic and specialized social care services. The experiences of social and school youth workers on the labor market also tended to converge: Both their earlier work experiences and recent job changes were characterized by mobility inside the profession-e.g., from the care of the elderly to the care of addicts. In the other group of interviewees, however, the dominant tendency was to be working in the field related to their second qualification (e.g., sales, the energy industry, call centers, conservation).

We also asked our respondents how marketable they thought their qualification was. School youth workers thought their chances of finding employment were favorable, as there was an ever-growing labor shortage in their field. They also pointed out, however, that there were very few dedicated school youth workers with great expertise, and, moreover, this profession was among the ones with the least prestige. They would further enhance the practical side of the training for better employability. They thought it was necessary to exercise stricter control of student attendance in field practices, to set stricter requirements, to promote active cooperation and communication between students and faculty, and to involve students in working with clients.

"At present, the position of my profession on the labor market is very poor and it is not sufficiently recognized, one of the reasons being the survival of the unfittest. This phenomenon is typical of our higher education as a whole, not only my profession". (youth worker no. 5)

Social workers, on the other hand, did not find it so easy to find employment, and repeatedly pointed out problems in the social sector, especially the lack of recognition by the public. There was an interviewee who found that, owing to the new training system introduced during the Bologna process, students had insufficient knowledge when receiving their BA. Altogether, however, social workers also recommended the improvement of practical training for greater employability. They stressed that students ought to be helped to spend their practice in institutions where field teachers gave them real guidance. The idea of dual training also came up as an innovative solution. In dual training, students spend almost as much time in practical training at a partner organization as in the higher education institution (Derényi 2016).

"There's a constant demand for our work, but it looks as if the government does not admit this, so there are no jobs for us except on the periphery. Let's take those who have been working in the profession for over ten years and have burnt out-they still continue, because they have no other choice. But in this way, there are no vacancies for the best and for fresh graduates". (social worker no. 5) 
As graduates see it, adult education is a very broad field, but rather ambivalent regarding employability. The interviews reflected what Nyüsti and Veroszta (2014) stated in their study, namely that arts graduates, regardless of their field of study, have skills and erudition that can be converted well at the workplace and in other areas of life. However, interviewees found it indispensable that students be familiarized with the methodologies of the tasks one encounters at work (e.g., compiling a training plan, organizing cultural events and activities). Teaching assistants were unanimous about the very low chances of finding employment with their qualification. They thought their course should be completed with a related discipline, such as lower primary teacher training, and they also encouraged a much closer cooperation between the university and potential employers. Furthermore, lecturers should inform students about what kinds of positions they are entitled to work in after graduation.

"Very few people are needed in our field, but prospects are quite promising in multinational companies. Obviously, knowledge of foreign languages is indispensable, as well as gaining work experience in your area of study. Without these, the chances of finding employment easily are rather slim". (adult educator no. 3)

There was an overlap again in social workers' and school youth workers' definitions of the social function of the knowledge they acquired during their studies: Empowerment, promoting social reintegration, sensitizing the public, and-after recognizing and identifying the problems-giving help using the methodology of social work. How adult educators see their own role in society includes facilitating people's cultural innovations, the appropriate organization of training events, and professional development training for individuals. The main tasks of teaching assistants-in their own view-are the integration of children with special needs and acting as facilitators in schools between teachers and students or teachers and parents. However, they feel they cannot fulfill that role in real life, which means they can utilize their training only if they wish to pursue an academic career.

"Unfortunately, social work is not a particularly popular occupation in Hungary, and its significance is not duly recognized by society. In spite of this, I believe that contributing to others' well-being and integrity and helping them in hard times are tasks which require a lot of responsibility". (social worker no. 2)

\subsection{Plans for the Future}

Finally, we herein sum up our findings about interviewees' plans for the future. Graduates in the social field generally considered continuing their studies in areas related to their present work (e.g., addiction consulting). The other group, on the other hand, did not plan on further studies, one of the reasons being that they had already obtained further qualifications after their BA.

Several social workers and school youth workers were considering changing jobs within their professions. What they thought would be instrumental in decreasing fluctuation was enhancing the reputation of the profession by giving it greater moral and financial prestige while lessening the workload (e.g., by reducing administrative tasks). In addition, they found it necessary that opportunities for preserving mental well-being should be provided (e.g., by supervision) and that cooperation within the profession should be improved (e.g., teamwork or workshops). Interviewees were also in favor of career aptitude tests for would-be students, as well as opportunities for personal development and promotion by the introduction of a career path model. Adult educators and teaching assistants also considered changing jobs, but typically outside their professions. One of the reasons was that they either completely distanced themselves from their chosen professions or they found that their chances of finding employment there were rather slim.

Social graduates' career visions contained the aspiration to become better helping professionals, to work more efficiently, and to treat clients at a high standard. In contrast, education graduates were still in search of their career paths; the options included finding employment in their professions, setting up their own businesses, or starting a career abroad. 
"I am not a careerist, and it gives me the utmost satisfaction if I can have a rest with my family after a good day's work knowing that I was able to help at least one teenager turning to me. If there's one single adolescent per year whose life takes a turn in the right direction with my help, that is the best reward for my work". (youth worker no. 5)

By way of summary, we established a typology based on the criteria we examined. The two groups were characterized by the following features (Figure 1):

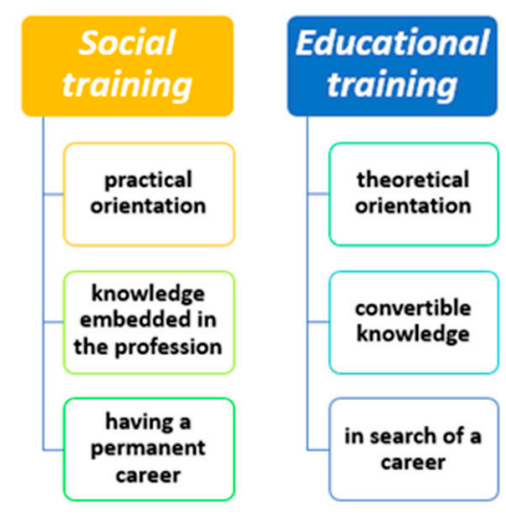

Figure 1. Typology based on the properties of the training programs.

\section{Conclusions}

Our research investigated social and educational helping professionals' experiences about their training, finding employment, and future plans. It is a case study that adds to the literature. Several researchers have examined how traditional educational practices prepare students for the labor market. However, no one in the Hungarian literature has pointed out that the content of the training does not correspond to the expectations of the labor market, nor the incongruence of theory and practice. We found that the content of the training and the preparation process were crucial to finding employment and having positive prospects. Practical experience gained during the training period, which is a major pillar of professional socialization, is inevitably important for young graduates. Owing to the contribution of these professions to the common good, one's chances of finding employment naturally depend on the number of vacancies created and financed by the state.

It turned out that the current training courses do not prepare the graduates for the tasks of the labor market. Higher education, with its traditionally theoretical profile, does not immediately react to the realities and challenges of society in every field, which hinders professional socialization. Although these fields are in need of workforce, there is also a need to align the content of the training with the social function fulfilled by these professions. All this requires the cooperation of higher education institutions as content providers and the non-governmental and business sectors as practice providers (employers).

The qualitative analysis showed that professionals whose training included more field exercises and supervision were more successful. They had increased their professional and social capital and helped them to integrate into the labor market. Graduates whose studies focused on theoretical knowledge reported difficulties finding employment and a lack of synthesis between theory and practice, which were negative outcomes of the Bologna process. On our part, we would recommend content- and practice-oriented education, more active collaboration between faculty and potential employers, more opportunities for intensive field practice, and the promotion of self-employment by teaching entrepreneurial skills. The training of adult educators has already been reformed in Hungary, whereas the training of teaching assistants has not undergone any change yet either in terms of educational policy or content. What makes the situation worse is that, mainly for financial reasons, the number of staff assisting teachers is very low in Hungary-there are very few teaching assistants and school welfare officers, and no pupil assistants at all. 
Our research showed that school youth workers and social workers were able to find employment, but they pointed out the problems of the labor market (lack of prestige and limited prospects for promotion). What social and educational helping professions have in common is that there is a high risk of attrition because of low salaries, which eventually leads to wasting human resources. The solution in this situation could be government measures increasing the appeal and retention rates of these professions.

Among the limitations of our research are the small, unrepresentative sample, the retrospective nature (we analyzed respondents' experiences in retrospect), and the lack of generalizability. However, we have not conducted standardized research, but have pointed out a new problem with the qualitative method. Once we have studied the problem, our future goal is to create a questionnaire that measures students' readiness based on the answers of the professionals. In this way, in the course of quantitative research with a large sample, we will be able to obtain feedback on those who have completed a career and on the formation of labor market needs in this field.

Author Contributions: Conceptualization, G.P. and C.C.; Methodology, G.P. and C.C.; Investigation, G.P. and C.C.; Writing-Original Draft Preparation, G.P. and C.C.; Writing-Review \& Editing, G.P. and C.C.; Funding Acquisition, G.P. and C.C. All authors have read and agreed to the published version of the manuscript.

Funding: Project No. 123847 has been implemented with the support provided from the National Research, Development, and Innovation Fund of Hungary, financed under the K_17 funding scheme.

Acknowledgments: This research was supported through the New National Excellence Program of the Ministry of Human Capacities.

Conflicts of Interest: The authors declare no conflict of interest.

\section{References}

Abbott, Ann Augustine. 1988. Professional Choices: Values at Work. Silver Spring: NASW.

Archer, Margaret Scotford, ed. 1982. The Sociology of Educational Expansion: Take-off, Growth and Inflation in Educational Systems. SAGE Studies in International Sociology 27. London: SAGE.

Balogh, Erzsébet, István Budai, Róbert Goldmann, Edit Puli, and Gábor Szöllősi. 2015. Felsőfokú szociális képzések Magyarországon. [Social Training Courses in Higher Education in Hungary]. Párbeszéd 2: 1-98. Available online: https://ojs.lib.unideb.hu/parbeszed/article/view/5817 (accessed on 15 August 2020).

Barretti, Marietta. 2004a. What Do We Know about the Professional Socialization of Our Students? Journal of Social Work Education 40: 255-83. [CrossRef]

Barretti, Marietta. 2004b. The Professional Socialization of Undergraduate Social Work Students. Journal of Baccalaureate Social Work 9: 9-30. [CrossRef]

Basham, Kathryn K., Susan Donner, Ruth M. Killough, and Lisa Werkmeister Rozas. 1997. Becoming an anti-racist institution. Smith College Studies in Social Work 67: 564-85. [CrossRef]

Becker, Howard S., Blanche Geer, Everett C. Hughes, and Anselm L. Strauss. 1961. Boys in White. Chicago: The University of Chicago Press.

Benkő, Brigitta. 2009. Szociálpedagógia szakos hallgatók a felsőoktatásban és a munkaerő-piacon. [Students of Youth Work in Higher Education and on the Labour Market]. Ph.D. dissertation, Debreceni Egyetem, Debrecen, Hungary, April 3.

Bernstein, Basil. 1971. Class, Codes and Control: Theoretical Studies towards a Sociology of Language. London: Routledge \& Kegan Paul.

Bowie, Stan L., and Helen Hancock. 2000. African Americans and Graduate Social Work Education: A Study of Career Choice Influences and Strategies to Reverse Enrollment Decline. Journal of Social Work Education 36: 429-48. [CrossRef]

Castro, Claudio de Moura, and Daniel C. Levy. 2001. Four Functions of Higher Education. International Higher Education 23: 5-6. [CrossRef]

Condon, Eileen, and Nancy Sharts-Hopko. 2010. Socialization of Japanese Nursing Students. Nursing Education Research 31: 167-70.

Coombs, Philip Hall. 1968. The World Educational Crisis. A Systems Analysis. New York: Oxford University Press. 
Csoba, Judit, Gunther Graßhoff, and Franz Hamburger, eds. 2014. Soziale Arbeit in Europa. Diskurse der Sozialarbeit, Europäisierung, soziale Bewegungen und Sozialstaat. Schwalbach am Taunus: Wochenschau Verlag.

Csók, Cintia. 2020. Labour Market Characteristics of Helping Professionals. Central European Journal of Educational Research 2: 66-75. [CrossRef]

Curtis, Katherine, Khim Horton, and Pam Smith. 2012. Student Nurse Socialization in Compassionate Practice: A Grounded Theory Study. Nurse Education Today 32: 790-95. [CrossRef]

Daniel, CarolAnn. 2007. Outsiders-Within: Critical Race Theory, Graduate Education and Barriers to Professionalization. Journal of Sociology E Social Welfare 34: 25-42. Available online: https://scholarworks. wmich.edu/jssw/vol34/iss1/3 (accessed on 15 August 2020).

Derényi, András. 2016. Kézikönyv a duális képzésról. [Handbook on Dual Training]. Budapest: Tempus Közalapítvány.

Dinmohammadi, Mohammadreza, Hamid Peyrovi, and Neda Mehrdad. 2017. Professional Socialization of Iranian BSN Students: A Grounded Theory Study. Journal of Caring Sciences 6: 359-69. [CrossRef]

Ferge, Zsuzsa. 1997. Social Policy Challenges and Dilemmas in Ex-socialist Systems. In Transforming Post-Communist Political Economies. Edited by Joan M. Nelson, Charles Tilly and Lee Walker. Washington: National Academies Press, pp. 299-321.

Goulding, Christina, and Michael Saren. 2010. Immersion, Emergence and Reflexivity: Grounded Theory and Aesthetic Consumption. International Journal of Culture, Tourism and Hospitality Research 4: 70-82. [CrossRef]

Holley, Karri A., and Barrett J. Taylor. 2009. Undergraduate Student Socialization and Learning in an Online Professional Curriculum. Innovative Higher Education 33: 257-69. [CrossRef]

Hungarian Central Statistical Office (KSH). 2018. Magyarország 2017. [Hungary 2017]. Available online: http://www.ksh.hu/docs/hun/xftp/idoszaki/mo/mo2017.pdf (accessed on 17 July 2020).

Hungarian Central Statistical Office (KSH). 2019. Üres álláshelyek száma és aránya, 2019. II. negyedév. [The Number and Rate of Vacancies, 2nd Quarter of 2019]. Available online: https://www.ksh.hu/docs/hun/ xstadat/xstadat_evkozi/e_qli027b.html (accessed on 12 June 2020).

Kleisz, Teréz. 2005. A népmúvelés és a szociális munka szakmásodása angolszász és magyar metszetekben. [The Professionalisation of Adult Education and Social Work in the English-Speaking World and Hungary]. Ph.D. dissertation, Debreceni Egyetem, Debrecen, Hungary, May 18.

Lodigiani, Rosangela, and Luca Pesenti. 2014. Public Resources Retrenchment and Social Welfare Innovation in Italy: Welfare Cultures and the Subsidiarity Principle in Times of Crisis. Journal of Contemporary European Studies 22: 157-70. [CrossRef]

Longres, John F., and Gary B. Seltzer. 1994. Racism: Its Implications for the Education of Minority Social Work Students. Journal of Multicultural Social Work 3: 59-75. [CrossRef]

Máté, Zsolt. 2018. Iskolai szociális munka. [School Social Work]. Párbeszéd 5: 1-22.

Miller, Shari E. 2010. A Conceptual Framework for the Professional Socialization of Social Workers. Journal of Human Behavior in the Social Environment 20: 924-38. [CrossRef]

Miller, Shari E. 2013. Professional Socialization: A Bridge between the Explicit and Implicit Curricula. Journal of Social Work Education 49: 368-86. [CrossRef]

Moran, James R. 1989. Social Work Education and Students' Humanistic Attitudes. Journal of Social Work Education 25: 13-19. [CrossRef]

Nagy, Krisztina. 2008. Segítő hivatásokat választó hallgatók pályaorientációja a "Partiumban”. [Career Orientation of Students Choosing Supporting Profession in Partium]. Ph.D. dissertation, Debreceni Egyetem, Debrecen, Hungary, December 12.

Nyüsti, Szilvia, and Zsuzsanna Veroszta. 2014. Hungarian Graduate Career Tracking 2013-Integration of Administrative Databases. Budapest: Educatio Társadalmi Szolgáltató Nonprofit Kft.

Pardeck, John T., and Richard L. McCallister. 1991. The Effects of Undergraduate Social Work Education and the Personal Growth and Development of Students. Education 111: 382-87.

Pusztai, Gabriella. 2011. A láthatatlan kéztől a baráti kezekig. Hallgatói értelmezö közösségek a felsőoktatásban. [From Invisible Hands to Friendly Hands. Interpretive Student Communities in Higher Education]. Budapest: Új Mandátum Könyvkiadó.

Pusztai, Gabriella, and Tímea Ceglédi, eds. 2015. Professional Calling in Higher Education. Challenges of Teacher Education in the Carpathian Basin. Nagyvárad and Budapest: Partium Könyvkiadó-Personal Problems Solution-Új Mandátum Könyvkiadó. 
Pusztai, Gabriella, and Péter Cs Szabó. 2008. The Bologna Process as a Trojan Horse: Restructuring Higher Education in Hungary. European Education 40: 85-103. [CrossRef]

Pusztai, Gabriella, Veronika Bocsi, and Tímea Ceglédi. 2016. A felsőoktatás hozzáadott értéke Közép-európai kontextusban. [The Added Value of Higher Education in a Central European Context]. In A felsőoktatás (hozzáadott) értéke. Közelitések az intézményi hozzájárulás empirikus megragadásához. [The (Added) Value of Higher Education. Approaches to the Empirical Understanding of Institutional Contribution]. Edited by Gabriella Pusztai, Veronika Bocsi and Tímea Ceglédi. Nagyvárad and Budapest: Partium Könyvkiadó-Personal Problems Solution-Új Mandátum Könyvkiadó, pp. 7-12.

Salisu, Waliu Jawula, Nahid Dehghan Nayeri, Ibrahim Yakubu, and Fatemeh Ebrahimpour. 2019. Challenges and Facilitators of Professional Socialization: A Systematic Review. Nursing Open 6: 1289-98. [CrossRef] [PubMed]

Sántha, Kálmán. 2010. A trianguláció és az MTMM-mátrix kapcsolata a pedagógiai kutatásban. [The Relationship between Triangulation and the MTMM Matrix in Pedagogical Research]. Iskolakultúra 20: 54-62.

Shinyashiki, Gilberto Tadeu, Isabel Amélia Costa Mendes, Maria Auxiliadora Trevizan, and René A Day. 2006. Professional Socialization: Students Becoming Nurses. Revista Latino-Americana de Enfermagem 14: 601-607. [CrossRef] [PubMed]

Shuval, Judith Tannenbaum. 1980. Entering Medicine: The Dynamics of Transition. A Seven Year Study of Medical Education in Israel. Oxford: Pergamon Press.

Stark, Joan S., Malcolm A. Lowther, Bonnie M. K. Hagerty, and Cynthia Orczyk. 1986. A Conceptual Framework for the Study of Preservice Professional Programmes in Colleges and Universities. The Journal of Higher Education 57: 231-58. [CrossRef]

Strauss, Anselm L., and Juliet Corbin. 1990. Basics of Qualitative Research: Grounded Theory Procedures and Techniques. Newbury Park: Sage Publication.

Strauss, Anselm L., and Juliet Corbin. 1998. Basics of Qualitative Research: Techniques and Procedures for Developing Grounded Theory. Thousand Oaks: Sage Publications.

Swank, Eric, Hideko Asada, and John Lott. 2001. Student Acceptance of a Multicultural Education: Exploring the Role of a Social Work Curriculum, Demographics, and Symbolic Racism. Journal of Ethnic \& Cultural Diversity in Social Work 10: 85-103. [CrossRef]

Szabó, Szilvia, ed. 2015. Jelentések a magyar felsőoktatás minőségéről. Párhuzamos vizsgálatok: egészségtudományi képzések. [Reports on the Quality of Hungarian Higher Education. Parallel Studies: Healthcare Training]. Budapest: Magyar Felsőoktatási Akkreditációs Bizottság.

Széll, Krisztián, Marianna Szemerszki, Zsuzsanna Veroszta, and Anikó Fehérvári. 2016. Diplomás pályakövetési rendszerek összehasonlítása Európában. [Comparison of Graduate Career Tracking Systems in Europe]. Budapest: Tempus Közalapítvány.

Van Soest, Dorothy. 1996. Impact of Social Work Education on Student Attitudes and Behavior Concerning Oppression. Journal of Social Work Education 32: 191-202. [CrossRef]

Vincze, Szilvia. 2010. A felsőoktatás és a munkaerőpiac inkongruenciája. [Incongruence between Higher Education and the Labour Market]. Ph.D. dissertation, Eötvös Lóránd Tudományegyetem, Budapest, Hungary.

Weaver, Hilary N. 2000. Culture and Professional Education: The Experiences of Native American Social Workers. Journal of Social Work Education 36: 415-28. [CrossRef]

Weidman, John C. 1989. Undregraduate Socialization: A Conceptual Approach. In Higher Education: Handbook of Theory and Research. Edited by John C. Smart. New York: Agathon Press, pp. 289-322.

Weidman, John C., Darla J. Twale, and Elizabeth Leahy Stein. 2001. Socialization of Graduate and Professional Students in Higher Education: A Perilous Passage? San Francisco: Jossey-Bass.

Weiss, Idit, John Gal, and Ram A. Cnaan. 2004. Social Work Education as Professional Socialization: A Study of the Impact of Social Work Education upon Students' Professional Preferences. Journal of Social Service Research 31: 13-31. [CrossRef]

Zarshenas, Ladan, Farkhondeh Sharif, Zahra Molazem, Mohammad Khayyer, Najaf Zare, and Abbas Ebadi. 2014. Professional Socialization in Nursing: A Qualitative Content Analysis. Iran Journal of Nursing and Midwifery Research 19: 432-38. [CrossRef]

(C) 2020 by the authors. Licensee MDPI, Basel, Switzerland. This article is an open access article distributed under the terms and conditions of the Creative Commons Attribution (CC BY) license (http://creativecommons.org/licenses/by/4.0/). 